\title{
O fotógrafo Romão Pereira \\ e a criação de uma paisagem tecnocientífica em Moçambique colonial (1886-1891)
}

\section{Photographer Romão Pereira and the Creation \\ of a Technoscientific Landscape \\ in Colonial Mozambique (1886-1891)}

Hugo Silveira PEREIRA*

Resumo Neste artigo, abordo o uso da fotografia na construção de uma paisagem tecnocientífica em contexto colonial. Para tal, analiso o caso das imagens que o fotógrafo português Manoel Joaquim Romão Pereira produziu sobre a então colónia portuguesa de Moçambique entre 1886 e 1891, e que estão preservadas no Arquivo Histórico Ultramarino (em Lisboa) e no Centro Português de Fotografia (no Porto). Partindo dos princípios de que a fotografia é uma ferramenta crucial na construção de paisagens e que essas não são fenómenos naturais, mas sim construções sociais, argumento que Romão Pereira, ao se focar em objetos da modernização técnica e científica de Moçambique, concorreu para a construção de uma ilusória paisagem tecnocientífica da colónia, que não representava fielmente a realidade local. Ao fazer isto, contribuiu para a representação de Portugal como um país avançado e com capacidade imperial, ao mesmo nível que outras nações coloniais da Europa.

Palavras-chave fotografia, História da Ciência e da Tecnologia, colonialismo

\footnotetext{
* https://orcid.org/0000-0002-7706-2686

NOVA School of Science and Technology, Departamento de Ciências Sociais Aplicadas, CIUHCT - Centro Interuniversitário de História das Ciências e da Tecnologia Campus da Caparica, 2825-149, Almada, Portugal hjs.pereira@fct.unl.pt
} 
AвSTRACT In this paper I analyse the use of photography to create a technoscientific landscape in the colonial context. To do so, I study the case of the images produced by Portuguese photographer Manoel Joaquim Romão Pereira about the then Portuguese colony of Mozambique between 1886 and 1891, which are preserved in the Arquivo Histórico Ultramarino (Lisbon) and in the Centro Português de Fotografia (Porto). Drawing from the principles that photography is a key instrument in the construction of landscapes and that these are not natural phenomena, but social constructs, I argue that Romão Pereira, by focusing in objects of technical and scientific modernization of the colony, contributed to the construction of an illusory technoscientific landscape in Mozambique, which did not represent faithfully the colonial reality. By doing so, he added to the representation of Portugal as an advanced country with imperial vocation, on the same level as other colonial nations of Europe.

KEYwORDS Photography, History of Science and Technology, Colonialism

\section{INTRODUÇÃO}

Em finais do século XIX, Portugal procurou afirmar a sua presença e soberania na sua colónia de Moçambique, na costa sudeste de África, a qual era cobiçada por outras nações imperiais, designadamente Inglaterra. Para esse feito, empreendeu a construção de diversas obras públicas e sistemas tecnocientíficos no sentido de fixar mais população, controlar e classificar os nativos e explorar os recursos do território e colónias vizinhas. Para divulgar esse investimento e esforço colonizador, o governo português contratou o fotógrafo Manoel Joaquim Romão Pereira, que produziu entre 1886 e 1891 três coleções fotográficas de Moçambique (posteriormente compiladas em álbuns com reproduções em albumina).

Neste artigo, analiso as fotografias de Romão Pereira que incluem aspetos relativos à modernização tecnocientífica da colónia e procuro 
perceber de que modo os colonialistas portugueses tentaram criar e divulgar através da fotografia uma imagem de Moçambique como um território moderno, europeizado e na senda do "progresso" e, consequentemente, apresentar o país como uma nação colonial de direito próprio e com capacidade para participar na missão de "civilizar" África (CONSTANTINI, 2008; HALL, 2002; JERÓNIMO, 2015). Nesse sentido, argumento que Romão Pereira tomou partido da objetividade atribuída à fotografia para contribuir para a construção de uma paisagem tecnocientífica de Moçambique, que promovia uma representação de Portugal como país imperial e moderno, enquanto legitimava a presença portuguesa como agente "civilizador". Contudo, essa paisagem construída não representava de todo a generalidade da realidade da colónia. Pretendo contribuir para o debate académico que vê a fotografia não apenas como uma mera fonte ilustrativa, mas sobretudo como um instrumento de império (LANDAU; KASPIN, 2002; RYAN, 1997; VICENTE, 2014a).

O artigo divide-se em cinco partes, além desta introdução onde apresento o problema: começo por caracterizar o contexto moçambicano de finais do século XIX, antes de descrever o percurso de Romão Pereira; em seguida, apresento o universo documental selecionado e a metodologia escolhida para o analisar; na discussão, analiso a forma como as fotografias de Romão Pereira procuraram construir uma paisagem tecnocientífica de Moçambique, assegurando a chegada do "progresso" à colónia; na conclusão, fecho o estudo com algumas reflexões finais.

\section{ConteXto Histórico}

Após a independência do Brasil, Portugal procurou em África um substituto económico para a antiga colónia (o mito do Eldorado) e uma base ideológica para um novo império, que afirmasse o país no concerto das nações (mito da herança sagrada). Contudo, a falta de recursos financeiros, a instabilidade política da primeira metade de Oitocentos e a representação de África como terra de degredo e morte limitaram o alcance dessa nova agenda colonial. Na segunda metade do século 
XIX, os governos portugueses começaram a dar mais importância e a investir mais largamente em Moçambique, com a criação de carreiras de vapor entre a metrópole e a colónia, a promoção do povoamento e exploração dos recursos locais, a construção de variadas obras públicas e a subjugação forçada de régulos locais que recusavam o domínio português. O tráfico de escravos foi progressivamente substituído pela agricultura de plantação (sésamo, milho, arroz) e pela exploração de minas e produtos locais, sem embargo de o trabalho forçado continuar a ser uma realidade. A partir das décadas de 1870-1880, a abertura do canal do Suez, a descoberta de jazidas de ouro e diamantes na África do Sul e a cobiça de outras nações europeias sobre os domínios portugueses (evidente nas conferências de Bruxelas e Berlim) reavivaram o interesse pelas colónias africanas. Os mitos do Eldorado e da herança sagrada foram reforçados e atualizados com uma agenda modernizadora assente em melhoramentos materiais e tecnocientíficos, como caminhos de ferro, estradas, hospitais, etc. (ALEXANDRE; DIAS, 1998, p. 25-97, p. 597-644).

A cidade de Lourenço Marques (atual Maputo) conheceu um considerável crescimento nas duas últimas décadas de Oitocentos. Desde o início do século XIX, sua baía atraía o comércio das regiões vizinhas, das quais era o porto natural (ALEXANDRE; DIAS, 1998, p. 567-584). Em meados da década de 1870, uma sentença arbitral do presidente francês Patrice de MacMahon (1873-1879) negou razão às pretensões inglesas sobre o território e confirmou a soberania portuguesa, ainda que os britânicos nunca tenham esquecido o desejo de anexar o território (JESSETT, 1900). Na década seguinte, foi construído um caminho de ferro entre Lourenço Marques e a fronteira com o Transval (e daí às minas de ouro do Witwatersrand). Depois de um diferendo com os investidores britânicos e estadunidenses, a ferrovia foi nacionalizada em 1889, o que motivou fortes protestos e disputas jurídico-diplomáticas com os governos daqueles dois países e recrudesceu a cobiça inglesa sobre o território (TELO, 1991, p. 31-103). Assim que ficou ligada às minas do Transval, em 1894, a linha-férrea tornou-se uma das mais movimentadas e lucrativas de toda a rede ferroviária 
colonial portuguesa (PORTUGAL, 1917), contribuindo ainda para transformar Lourenço Marques numa cosmopolita cidade. Em 1898, Lourenço Marques tornou-se capital de Moçambique.

Mais a norte, na Zambézia, famílias de colonos exploravam alguns recursos locais, enquanto contribuíam para estender a influência da soberania portuguesa no território. O movimento comercial era escoado por Quelimane, que, ao longo de Oitocentos, se tornou um porto com alguma importância. Papel semelhante desempenhou o porto da Beira em relação aos distritos de Manica e Sofala (e mais tarde em relação à Rodésia, atual Zimbabwe), sobretudo após a formação da Companhia de Moçambique em 1891, à qual foram atribuídos poderes majestáticos para gerir o território, e com a construção da linha da Beira à fronteira com os territórios rodesianos (ALEXANDRE; DIAS, 1998, p. 586, p. 634-642; MARQUES, 2001, p. 476-481; PEREIRA, 2019).

Contudo, a efetiva presença portuguesa em Moçambique era escassa e limitada a pequenas faixas de terra, competindo com a influência do capital inglês que financiava muitos dos projetos coloniais portugueses. Adicionalmente, os anos em que Romão Pereira tirou as suas fotos coincidem com o ultimato britânico de 15 de janeiro de 1890 (pelo qual Inglaterra exigiu que Portugal abandonasse as suas pretensões de ocupação dos territórios entre Angola e Moçambique) e com o recrudescimento da sacralização do império que se lhe seguiu (ALEXANDRE; DIAS, 1998, p. 115-119; TEIXEIRA, 1987).

\section{A fotografia em Portugal, o fotógrafo Romão PEReira E OS SEUS TRABALHOS FOTOGRÁficos}

A fotografia era uma técnica conhecida e praticada em Portugal desde a década de 1840, quando vários jornais noticiaram a sua invenção em França e diversos fotógrafos estrangeiros se instalaram no país. $\mathrm{Na}$ década seguinte, muitos fotógrafos portugueses seguiram as mesmas pisadas, dedicando-se à atividade. A fotografia passou a ser usada como instrumento de trabalho (de engenheiros, astrónomos, topógrafos, médicos), de exposição, de registo criminal e até de falsificação de notas. 
Desde a década de 1860, era ministrada no ensino superior (cursos de engenharia) e em cursos livres vocacionados para amadores. Segundo Jill Dias (1991, p. 67), desde essa década que a fotografia começou também a ser praticada nas colónias portuguesas. Até finais do século XIX, era uma atividade reservada aos mais ricos, em virtude do alto preço dos equipamentos e materiais acessórios. A partir dos últimos anos do decénio de 1880, várias inovações simplificaram e embarateceram os processos fotográficos, tornando-os mais acessíveis a franjas mais vastas da população (SENA, 1998, p. 13-199).

No contexto colonial português, sobretudo em Moçambique, destacaram-se vários fotógrafos portugueses e estrangeiros, que captaram nas suas imagens aspetos diversos da presença europeia na colónia (DIREITO, 2014; FERNANDES, 2014; GOMES, 2016; SANTANA, 2014; SILVA, 2014). Um desses fotógrafos foi Manoel Joaquim Romão Pereira, cujas fotografias analiso neste artigo.

Manoel Joaquim Romão Pereira foi um fotógrafo português, natural de São Bartolomeu de Messines, no distrito de Faro (antiga província do Algarve), onde nasceu em 1815. Dedicou-se ao comércio colonial, antes de se mudar, em 1877, para Cabo Verde, como funcionário do governo local, já numa fase tardia da sua vida (62 anos). Pouco depois, em 1880, migrou para Moçambique, onde se dedicou à fotografia. Em 1886, começou a colaborar com o governo português, que lhe encomendou uma reportagem fotográfica do caminho de ferro de Lourenço Marques. ${ }^{1} \mathrm{O}$ trabalho prolongou-se por alguns anos. Mais tarde, em 1889, foi novamente contratado pelo governo português para chefiar uma expedição fotográfica e captar em imagens a geografia e a população de Moçambique, bem como exemplos da presença portuguesa naquela colónia africana (DIAS, 1991, p. 75). Em ambos os casos, tudo indica que Romão Pereira tenha sido responsável pela compra de

1 Segundo a descrição do álbum da reportagem. CENTRO PORTUGUÊS DE FOTOGRAFIA (CPF), Porto. Collecção de photographias relativas ao caminho de ferro de Lourenço Marques, 1889-1898. Disponível em: <digitarq.cpf.arquivos.pt/details?id=1208273digitarq.cpf.arquivos. pt/details?id=1208273>. Acesso em: 25 jan. 2021. 
todo o material fotográfico necessário - em 1889, era composto por equipamento adquirido ao cônsul inglês em Moçambique, que pertencera ao fotógrafo inglês Dejoux, vítima mortal de febre nas proximidades dos lagos Chilwa e Chiuta (DIAS, 1991, p. 77). No âmbito do serviço prestado ao governo português, acompanhou o diplomata luso, Mariano Cirilo de Carvalho, numa visita à colónia, logo após o ultimato de 1890. A sua biógrafa descreve-o como um patriota preocupado com a evolução de Lourenço Marques e que detestava os ingleses. Pelos seus trabalhos em Moçambique, foi admitido como sócio da Sociedade de Geografia de Lisboa, uma instituição que defendia uma vincada agenda imperial para os territórios ultramarinos (PEREIRA, 2013, p. 23-24, p. $67-72$, p. 87 , p. $99-105){ }^{2}$

O seu percurso de vida e carreira fotográfica foram analisados detalhadamente por Luísa Vilarinho Pereira (2013), que fornece os principais dados biográficos e arrola os principais acervos de Romão Pereira. Antes, Dias (1991, p. 75-77) fez uma breve menção a fotografias suas tiradas entre Quelimane e os rios Zambeze e Chire, num estilo romantizado que enfatizava o exotismo da paisagem e dos habitantes. Mais recentemente, Fernandes (2014) analisou as imagens produzidas no contexto da missão de Mariano de Carvalho, realçando como fotos de melhoramentos materiais e da presença militar lusa foram usadas para evidenciar o domínio colonial português.

Neste artigo, foco a minha atenção nos detalhes tecnocientíficos das fotografias de Romão Pereira em três das suas coleções: África Oriental - Província de Moçambique. Colonias Portuguesas - Lourenço Marques (adiante citado como África Oriental; 93 imagens); Missão de Mariano Cyrilo de Carvalho à província de Moçambique (adiante Missão de Mariano de Carvalho; 116 imagens); e Collecção de Photographias relativas ao Caminho de Ferro de Lourenço Marques (adiante Caminho de ferro de Lourenço Marques; 47 imagens) - ver figura 1 para um mapeamento destas imagens.

2 Sobre a Sociedade de Geografia de Lisboa, ver: GUIMARÃES, 1984. 
Figura 1: Localizações aproximadas das fotos de Romão Pereira

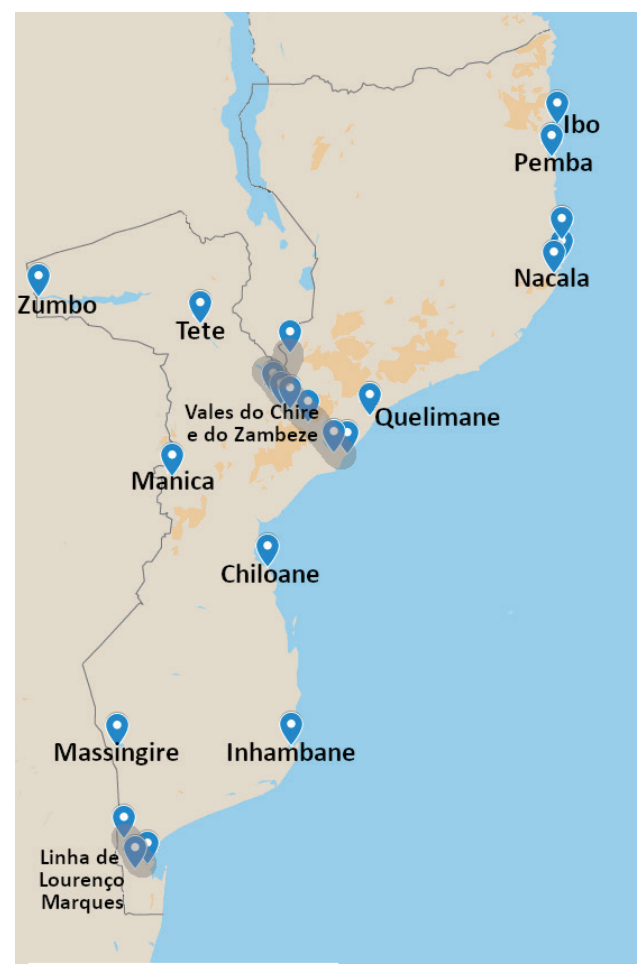

Fonte: Elaboração própria a partir das informações das fotos e da aplicação web Google My Maps

As duas primeiras coleções estão preservadas no Arquivo Histórico Ultramarino (AHU) em Lisboa, enquanto a terceira se encontra à guarda do Centro Português de Fotografia (CPF) no Porto. Todas se encontram disponíveis online. ${ }^{3}$ Essas coleções não contêm as imagens

3 O primeiro ARQUIVO HISTÓRICO ULTRAMARINO (AHU), Lisboa. África Oriental - Província de Moçambique. Colonias Portuguesas - Lourenço Marques. Comissionado do Governo Portuguez em Moçambique, 1889-1891. Disponível em: <actd.iict.pt/collection/actd:AHUC196>; o segundo AHU, Lisboa. Missão de Mariano Cyrilo de Carvalho à província de Moçambique: edição geral, 1890. Disponível em: <actd.iict.pt/collection/actd:AHUC187>; e o terceiro CPF, Porto. Colleç̧ão de photographias relativas ao caminho de ferro de Lourenço Marques, 1889-1898. Disponível em: < digitarq.cpf.arquivos.pt/details?id=1208273>. Acessados em: 2 jan. 2021. 
originais, mas sim reproduções em albumina, uma técnica muito comum na época (SENA, 1998, p. 90). Para a sua análise, terei em atenção trabalhos semelhantes sobre outros fotógrafos coloniais (ALINA, 1997; GOMES, 2016; ROCHA; MATOS, 2019) e seguirei a metodologia que descrevo na secção seguinte.

\section{Metodologia E CONCEITOS METOdológicos}

Para analisar esses corpora documentais, considero-os elementos de cultura visual, um campo que se interessa por "eventos visuais nos quais o utilizador procura informação, significado ou prazer numa relação com uma tecnologia visual"4 (MIRZOEFF, 2002, p. 5-6). Neste caso, o utilizador refere-se tanto ao fotógrafo como aos observadores do seu trabalho e a tecnologia visual é a fotografia. Considerando ainda que as fotografias não são fontes isentas nem tampouco objetivas e por isso não podem ser tomadas pelo seu "valor facial", há que estabelecer um conjunto de regras e critérios para a sua análise.

No período analisado, a fotografia, como produto da ciência e da tecnologia, que obedecia às leis da física e da ótica, era encarada como um instrumento completamente mecânico e, portanto, os seus produtos eram pensados como totalmente objetivos e infalíveis na reprodução perfeita da realidade. Refletindo o positivismo da época, contrastava com outras representações gráficas, como pinturas, gravuras ou desenhos, que estariam feridas pela subjetividade dos seus autores (PAVAN, 1991, p. 233).

Todavia, a fotografia era igualmente um produto subjetivo, desde logo pela escolha do ângulo, da pose dos personagens, da exposição, do tipo de película, etc., mas sobretudo pela própria escolha do objeto retratado (DUBOIS, 1992, p. 29) e ainda pelos objetivos e exigências de

4 Trad. livre do autor: "visual events in which the user seeks information, meaning or pleasure in an interface with visual technology". 
quem encomendou ou pagou as fotos (FREUND, 1995, p. 20). ${ }^{5}$ Como refere Sontag (1986, p. 34), "fotografar é conferir importância" a um determinado objeto, a qual depende do sistema de valores do fotógrafo, da pessoa ou entidade que o contratou para realizar a tarefa e da audiência provável das imagens. Azoulay (2008, p. 122-123) argumenta que o observador é elemento ativo no ato fotográfico e tem responsabilidade sobre o que o fotógrafo decide tornar visível. Como corolário, Allina (1997, p. 10) defende que o público presumível da foto influencia o trabalho do fotógrafo.

No caso de Romão Pereira, já vimos que era um fotógrafo que se dedicou à prática fotográfica numa fase tardia da sua vida, já depois de migrar para as colónias, e que defendia uma política colonial mais assertiva para Moçambique, no sentido de afastar a influência e pretensões britânicas sobre a região. Com esses objetivos, estava alinhado ao governo metropolitano, que o contratou para realizar uma reportagem fotográfica sobre o território, evidenciando a presença e colonização portuguesa. Uma das expectativas do projeto, tanto do governo como de Romão Pereira, seria certamente a sua divulgação por um público mais vasto, a quem deveria ser transmitida a mensagem de que Portugal assumia sem hesitações a sua vocação imperial e concorria efetivamente para o desenvolvimento material da colónia (a reprodução das fotos em albumina indicia isso mesmo). De facto, algumas das fotos de Romão Pereira circularam na imprensa (PEREIRA, 2013, p. 68, p. 97; MARTINS, 2014, p. 115) e foram expostas na Exposição Insular e Colonial do Palácio de Cristal do Porto, na metrópole (FERNANDES, 2014, p. 196-197).

Em suma e ao contrário da interpretação coeva, a fotografia era um instrumento e um produto subjetivos, mas, ao se apresentar e ser aceite como um instrumento objetivo, disfarçava aquela subjetividade

5 Adicionalmente, mesmo a premissa de que a fotografia representa algo que existiu no espaço e no tempo pode ser posta em causa, uma vez que era sempre possível manipular a imagem final. Isso acontecia frequentemente na reprodução de fotos na imprensa ilustrada (BEEGAN, 2008, p. 177) e também noutros meios (como álbuns de albuminas). 
como um facto indiscutível, tendo-se tornado por isso num poderoso instrumento para produzir ideologia (PHU, 2017, p. 288-289). Desse modo, constitui uma excelente fonte para entender a criação de representações socioculturais sobre um determinado objeto histórico e a sua difusão por grupos mais amplos.

No caso do contexto colonial português, a fotografia tornou-se progressivamente um exercício de cultura visual que não só ilustrava e demonstrava a expansão do colonialismo luso, como construía paisagens específicas dos territórios ultramarinos para divulgação na metrópole. Estudos recentes têm demonstrado como a fotografia (além de outros meios visuais, como desenhos e gravuras) reproduzia e reforçava a ideia da inferioridade civilizacional dos africanos e a superioridade civilizacional dos portugueses, enquanto legitimava a "missão civilizadora" de Portugal em África (GOMES, 2016; MATOS, 2006, p. 83-94; PEREIRA, 2020, p. 193; ROCHA; MATOS, 2019; VICENTE, 2014a), sobretudo ao encontrar respaldo na imprensa ilustrada (MARTINS, 2014, p. 89-148). Para muitos na metrópole, esse era o único contacto que tinham com as colónias, sendo adicionalmente, um contacto persuasivo, em virtude da já mencionada alegada objetividade da fotografia (RYAN, 2014, p. 39). As imagens de Romão Pereira também se incluem nesse processo imperial e procuraram realçar a intensificação da presença portuguesa no período analisado, a qual vinha sendo posta em causa pela influência do capital financeiro inglês e pelo próprio ultimato de 1890 .

Nas imagens fotográficas propriamente ditas, há também um conjunto de detalhes a ter em consideração. Como indiquei, a presença de elementos tecnocientíficos é o critério de seleção. Para aplicar esse critério, sigo a definição de tecnologia sugerida por Headrick (2010, p. 3): todas as formas pelas quais os homens usam os materiais e energia no ambiente para os seus próprios usos, além daquilo que conseguem fazer com os seus próprios corpos. A partir daqui, interessa-me o peso da presença desse tipo de imagens no acervo e a repetição de certos ícones tecnocientíficos ao longo da coleção. Assim, das 256 imagens de Romão Pereira constantes dos álbuns supramencionados, 197 (77\% da amostra; 70, 80 e 47 nas três coletâneas, respetivamente) incluem 
elementos tecnocientíficos, incluindo artefactos (armamento, instrumentos, máquinas), sistemas (caminhos de ferro, portos), edifícios (alfândegas, quartéis, correios) ou transformações na paisagem (arruamentos, cidades).

Para completar a análise, o exame de documentação escrita associada à fotografia é imprescindível, uma vez que a cultura visual não pode ser dissociada da cultura escrita que lhe está subjacente (VICENTE, 2014b, p. 12). Nesse sentido, um aspeto torna-se essencial na análise: a legenda da imagem, que de imediato influencia o olhar do observador (FRANKLIN; BECKLEN; DOYLE, 1993) e revela o detalhe que o fotógrafo mais valoriza - o punctum da foto, para usar a expressão de Barthes (1980, p. 46). Além da legenda, importa incluir na análise outras fontes textuais associadas às imagens. No caso do acervo Romão Pereira, as fotos não foram acompanhadas de quaisquer textos específicos. Contudo, tendo em conta que uma grande parte do trabalho foi encomendada pelo governo da metrópole, recorrerei a debates parlamentares e a diversos estudos de diferentes autores sobre Moçambique e o projeto colonial ali implementado. ${ }^{6}$

Para terminar esta secção, considerando que arguo que Romão Pereira contribuiu para criar uma "paisagem tecnocientífica" de Moçambique, faço uma pequena reflexão sobre esse conceito. Muitos autores já falaram da paisagem não como um objeto que possa ser visto ou lido, mas como uma construção humana, cultural e um processo pelo qual identidades sociais e subjetivas se formam (JACKSON, 1984; MITCHELL, 1994; NYE, 1999). Mais recentemente, Kelsey (2016, p. 71) realçou o crucial papel da fotografia na construção de paisagens. Ao focar repetidamente a objetiva de uma câmara num aspeto particular de uma paisagem (disfarçando, obscurecendo ou omitindo todos os demais elementos), pode criar-se uma paisagem específica de um território: uma paisagem natural (se se focar nos caprichos da natureza), uma paisagem urbana (se se focar nas cidades de um território) ou uma

6 Sobretudo aqueles publicados pelo parlamento no periódico Diário da Câmara dos Deputados. Disponível em: < debates.parlamento.pt/ >. Acesso em: 06 jul. 2021. 
paisagem tecnocientífica (se se focar em aspetos tecnocientíficos). No caso em análise, Romão Pereira, ao focar a sua objetiva nos melhoramentos técnicos e urbanos de Moçambique e ao obscurecer todos os outros elementos da paisagem (caprichos naturais, aldeias nativas, território não ocupado por colonos), criou uma imagem ilusória de que toda ou grande parte da colónia se europeizara, algo que estava (e sempre esteve) muito longe de ser uma realidade.

\section{RELANCES DE UM IMPÉRIO TECNOCIENTÍFICO: as fotografias de Romão Pereira}

Da análise detalhada dos álbuns de Romão Pereira, nota-se que o fotógrafo algarvio acompanhou, grosso modo, os modelos de representação de África que outros fotógrafos coevos seguiram: um continente exótico, mas subdesenvolvido, com populações tidas como primitivas e cuja modernização era anunciada com entusiasmo. No entanto, ao contrário de outros álbuns de fotógrafos profissionais (como o de Cunha Moraes, em Angola, ou o do caminho de ferro de Lourenço Marques de C. S. Fowler) ou de engenheiros coloniais, ${ }^{7}$ nota-se alguma ausência de sentido estético e um estilo quase naïf das suas fotos, próprias de um amador ou um autodidata que se iniciava na arte - aliás, a fraca composição (e organização dos elementos) das imagens, alguma monotonia temática, falta de foco ou nitidez de algumas imagens (não completamente justificável pelo desgaste provocado pelo tempo) dão a entender isso mesmo. Desse modo, os álbuns analisados neste artigo fornecem-nos o olhar de um colono comum que se interessou pela fotografia nos últimos anos da sua vida e não a do "fotógrafo-artista" ou a do técnico que se propunha a levar o "progresso" até África - e aqui reside a originalidade das fotografias de Romão Pereira.

7 Ver, respetivamente, ROCHA; MATOS, 2019; GOMES, 2016; PEREIRA, 2020.

8 Em relação a Cunha Moraes, Jill Dias (1991, p. 69) refere que embora a sua principal preocupação fosse mais educacional e propagandista do que artística, é evidente que as duas dimensões não são mutuamente exclusivas. 
Olhando para as imagens, nota-se claramente uma atração pelas modernizações técnicas e europeização do território, visíveis em 77\% da amostra. Essa escolha acaba por não ser surpreendente - vai também ao encontro da conclusão do estudo de Fernandes (2014, p. 205-206) tendo em conta que, por essa altura, ciência e tecnologia eram a bitola pela qual se media o grau de civilização das diferentes nações (ADAS, 1989 , p. 134) e que, no contexto colonial, demonstravam a "missão civilizadora" dos países europeus e a legitimidade da sua presença naqueles territórios (HEADRICK, 2010, p. 5-6, p. 370).

Esta é indubitavelmente a principal e mais óbvia mensagem transmitida pelas imagens: considerando que o pensamento da época equivalia "progresso", "civilização" e desenvolvimento a grandes sistemas tecnológicos e obras públicas, Portugal vinha se esforçando para trazer a "modernidade" a Moçambique, mostrando ao mesmo tempo a sua capacidade para empreender uma "missão civilizadora" como outras nações imperiais o faziam. ${ }^{9}$

As fotografias constituíam provas da aplicação do programa sugerido por vários tecnocratas e engenheiros coloniais, como por exemplo Joaquim José Machado (um dos mais influentes técnicos ultramarinos), que garantia que

muitos quilómetros de estradas e vias férreas é o que as nações cultas têm a fazer na África, se quiserem seguir o caminho mais direto e eficaz para terminarem a escravidão da raça negra, promover o seu aperfeiçoamento moral e intelectual, e aproveitar as consideráveis riquezas naturais de tão extenso território (citado por NAVARRO, 2018, p. 347).

Além dessa mensagem genérica, as fotografias possuem detalhes importantes e mensagens específicas, que contribuem para analisar as

9 Sobre as agendas coloniais "civilizadoras" britânica, francesa e portuguesa, ver, respetivamente: HALL, 2002; CONSTANTINI, 2008; JERÓNIMO, 2015. 
representações que existiam tanto sobre Moçambique e seus habitantes nativos, como sobre a tecnologia e o colonialismo português.

Alguns dos aspetos captados por Romão Pereira foram as instalações portuárias de Moçambique (Lourenço Marques, Inhambane, Quelimane, Nacala, Chiloane - figura 2). Ainda que essas infraestruturas fossem tudo menos impressionantes (as grandes obras nos portos da Beira e Lourenço Marques teriam de esperar pelos primeiros anos do século $\mathrm{XX}$ ), não deixavam de ser portas de entrada no império e portais que promoveriam a globalização das riquezas que se imaginava existir nos respetivos hinterland (PEREIRA, 2018). Essa representação encontrava respaldo no parlamento da metrópole, onde muitas vezes se discutia a necessidade de investir nos portos coloniais, como o de Lourenço Marques, "para poder satisfazer ás vastissimas transacções a que está destinado a occorrer" - como argumentava a comissão de marinha e ultramar num parecer sobre a contratação de linhas de navegação entre os portos de Moçambique. ${ }^{10}$ Simultaneamente, as fotos de Romão Pereira denunciavam a falta de investimento que muitos colonialistas também lamentavam: o deputado António Maria de Carvalho, durante a discussão no parlamento do orçamento para o ultramar, confessou que preferia

á estação civilisadora no Zaire, uma ponte de desembarque em cada uma das nossas colonias (...); a construcção dos pharoes precisos para illuminar-lhes as suas costas; os guindastes precisos para carregar e descarregar mercadorias; (...) porque é uma vergonha para nós, e um embaraço para o commercio, que as cousas continuem como se encontram actualmente. $^{11}$

10 PORTUGAL. Câmara dos Senhores Deputados da Nação Portugueza. Diário da Câmara dos Deputados, 18 maio 1883. No 88, p. 1567.

11 PORTUGAL. Câmara dos Senhores Deputados da Nação Portugueza Diário da Câmara dos Deputados, 23 jun. 1882. № 116, p. 1944. 
Figura 2: Cais da alfândega no porto de Quelimane

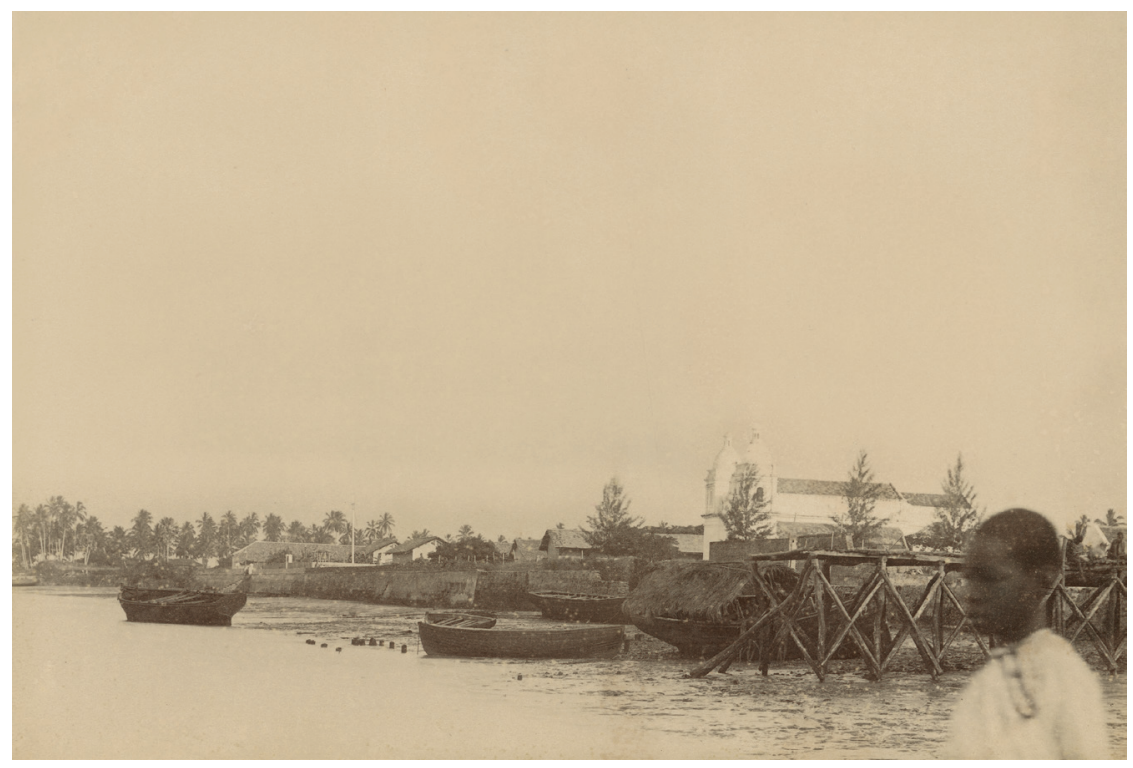

Fonte: AHU, Lisboa. PEREIRA, Manoel Romão, Quelimane - perspectiva da vila de Quelimane ao desembarque no caes da alfandega. África Oriental, 1889-1891. Disponível em: <actd.iict.pt/ view/actd:AHUD6321>. Acesso em: 3 jan. 2021.

Um outro importante instrumento de império era o telégrafo, o qual chamou também a atenção de Romão Pereira. ${ }^{12}$ No contexto colonial, o telégrafo assumia uma dupla relevância: prática e simbólica. Se, por um lado, agilizava a comunicação e a ligação comercial, diplomática e militar entre metrópole e colónias (HEADRICK, 1981, p. 163-164), por outro, era um ícone de modernidade. Esses entendimentos eram também partilhados coevamente entre os tecnocratas nacionais, como por exemplo o visconde de Chanceleiros, ministro das obras públicas em 1892, que reconhecia que

12 AHU, Lisboa. PEREIRA, Manoel Romão, Lourenço Marques - Estação Telegráphica do Cabo Submarino, Missão de Mariano de Carvalho, 1890. Disponível em: <actd.iict.pt/view/actd: AHUD6416>. Acesso em: 3 jan. 2021. 
os cabos submarinos não são instrumento de guerra, mas de paz, de progresso e de civilisação. Approximam os povos que a natureza separou e dividiu por distancias, que tornaram impossivel a rapida transmissão da idéa e dos factos como o exigem as condições da moderna civilisação. ${ }^{13}$

Romão Pereira não quis deixar de testemunhar que Portugal instalara também esta importante ferramenta em Moçambique.

Independentemente das expectativas de paz e cooperação suscitadas pela tecnologia, ela servia também para a guerra, sendo particularmente importante no contexto da disputa territorial com Inglaterra. Era, assim, importante mostrar algum poderio bélico, ainda que as possibilidades de um confronto com Inglaterra fossem baixas (e as probabilidades de vitória ainda mais baixas). Bem mais importante era a demonstração de que as autoridades coloniais tinham força tecnológica suficiente para dominar as populações locais. Nessa altura, registaram-se várias campanhas militares (ditas de "pacificação" e "ocupação", mas, na verdade, de invasão) no centro e norte de Moçambique (MANGOELE, 2015, p. 28-40; PÉLISSIER, 1984) contra grupos nativos que, para todos os efeitos, resistiam a uma invasão estrangeira. Era necessário mostrar força militar, tanto para assegurar a futuros colonos que o território era seguro, como para testemunhar que Portugal tinha capacidade para ocupar o território e impor a sua ordem. Nesse sentido, Romão Pereira fotografou diversas instalações militares (e de segurança pública, como quarteis, paióis, esquadras, cadeias) e alguns instrumentos de guerra, (além de vetustos canhões, também barcos canhoneiros e armamento em exercícios militares - ver figura 3). ${ }^{14}$

13 PORTUGAL. Câmara dos Senhores Deputados da Nação Portugueza. Diário da Câmara dos Deputados, 30 mar. 1892. No 55, p. 55.

14 Ver adicionalmente: AHU, Lisboa. PEREIRA, Manoel Romão, Quelimane - Quartel do Batalhão, África Oriental, 1889-1891. Disponível em: <actd.iict.pt/view/actd:AHUD6328>; AHU, Lisboa. PEREIRA, Manoel Romão, Bahia de Quelimane - Canhoeiro Zaire que condusiu a Commissão de Máximo [sic] de Carvalho, África Oriental, 1889-18891. Disponível em: <ctd.iict.pt/view/actd:AHUD6333>; AHU, Lisboa. PEREIRA, Manoel Romão, Frente 
Figura 3: O novo edifício da cadeia civil do distrito de Lourenço Marques

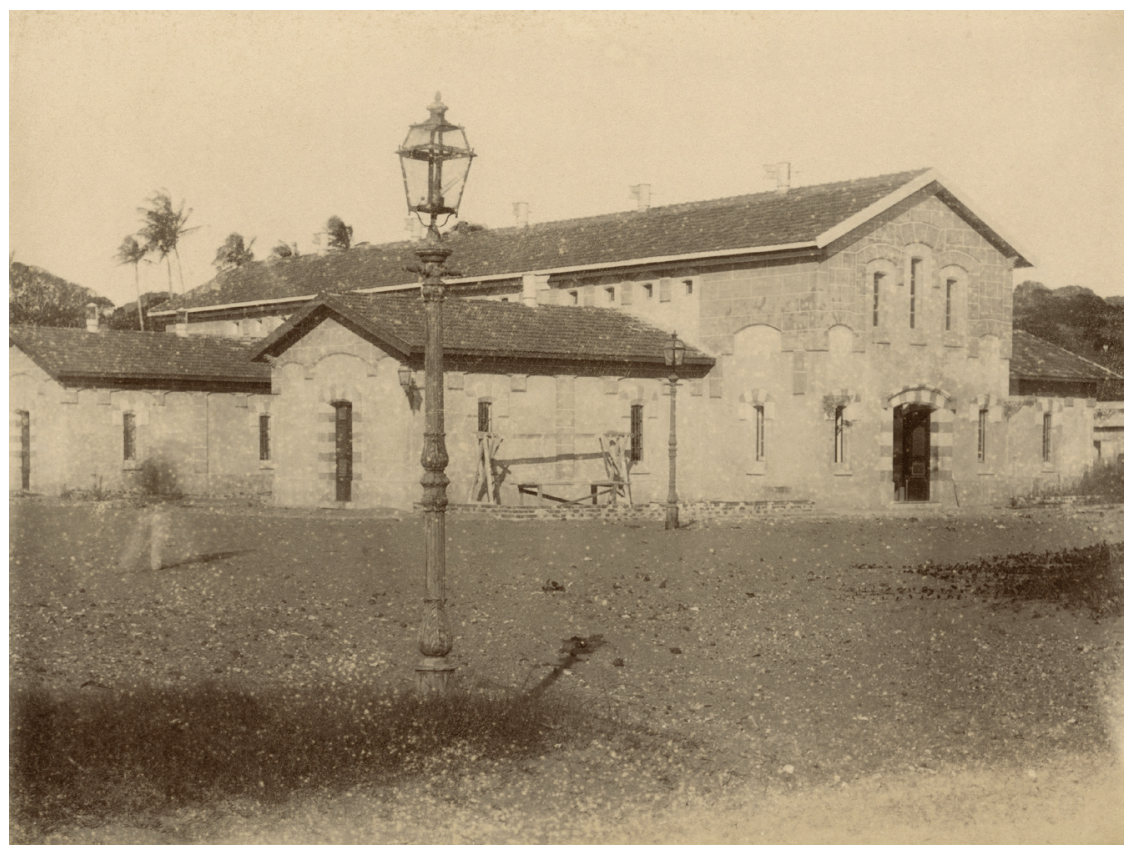

Fonte: AHU, Lisboa. PEREIRA, Manoel Romão, Lourenço Marques - Cadeia Civil do Districto, África Oriental, 1889-1891. Disponível em: <actd.iict.pt/view/actd:AHUD6341>. Acesso em: 3 jan. 2021.

Ainda que esses exemplos de tecnologia fossem importantes elementos das agendas coloniais, a tecnologia ferroviária continuava a ser a pioneira da "civilização" (ADAS, 2006, p. 79-80) e veículo mais emblemático do sublime técnico, isto é, o prazer de ver uma máquina em funcionamento como triunfo do génio humano (KASSON, 1976,

ao novo quartel de Polícia, África Oriental, 1889-18891. Disponível em: <actd.iict.pt/view/ actd:AHUD6351>. AHU, Lisboa. PEREIRA, Manoel Romão, Caçadores n. 1 Prompto a receber uma carga de cavalaria, Missão de Mariano de Carvalho, 1890. Disponível em: <actd. iict.pt/view/actd:AHUD6471>. AHU, Lisboa. PEREIRA, Manoel Romão, Peças de bronze, Missão de Mariano de Carvalho, 1890. Disponível em: < ctd.iict.pt/view/actd:AHUD6484>. Acessos em: 3 jan. 2021. 
p. 162-180). De tal modo assim foi, que o governo português encomendou a Romão Pereira uma coleção dedicada inteiramente ao caminho de ferro de Lourenço Marques (muito possivelmente para rivalizar com o álbum produzido e publicado pelos concessionários ingleses da linha em 1887)..$^{15}$ Os outros dois álbuns contêm igualmente imagens ferroviárias, mas foco-me sobretudo no álbum guardado no $\mathrm{CPF}$, que, para os efeitos que pretendo, oferece uma maior uniformidade temática.

Originalmente, a linha tinha sido concessionada ao estadunidense Edward McMurdo (em 1883), que mais tarde trespassou a concessão a uma firma inglesa. Por falta de capital, a construção só se iniciou em 1887, inicialmente sob direção de técnicos portugueses do Estado e depois por engenheiros britânicos. Em finais de 1888, esses davam a construção por terminada, embora o governo português argumentasse que ainda faltava um trecho de $9 \mathrm{~km} .{ }^{16}$ Para piorar a situação, a época das chuvas provocara estragos consideráveis na infraestrutura. Para resolver a questão, o governo português nacionalizou a linha e concluiu a obra usando os seus próprios recursos (TELO, 1991, p. 46-166).

Serve esse curto parágrafo para ilustrar o clima de conflito entre os agentes ingleses e o governo português. Romão Pereira também procurou demonstrar essa incúria recorrendo à fotografia, retratando diversas obras erigidas pelos ingleses em ruínas e mostrando as mesmas obras depois de reparadas pelos portugueses. Este exercício de "antes e depois" (figuras 4 e 5) transmitia a mensagem de como a perícia nacional tinha conseguido reparar o desleixo dos empreiteiros ingleses, que na metrópole eram acusados de dolosamente pretenderem prejudicar os interesses portugueses na região.

15 Sobre este álbum, ver: GOMES, 2016.

$16 \mathrm{O}$ problema nasceu do facto de a fronteira entre Moçambique e o Transval não estar ainda completamente definida entre as duas nações. 
Figuras 4 e 5: A ponte sobre a ribeira de Chicongene no caminho de ferro de Lourenço Marques. Destruída durante a época das chuvas (acima) e reerguida pelos técnicos portugueses (abaixo)

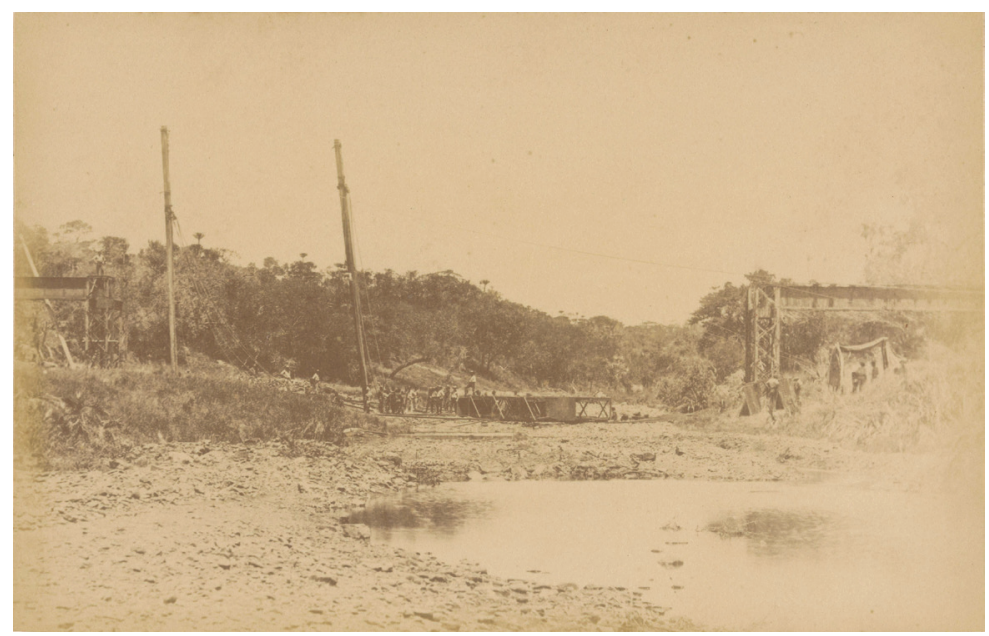

Fonte: CPF, Porto. Caminho de Ferro de Lourenço Marques, Ruínas da ponte de Chicongene depois das cheias de janeiro de 1889. Disponível em: <digitarq.cpf.arquivos.pt/details?id=1208376>. Acesso em: 3 jan. 2021.

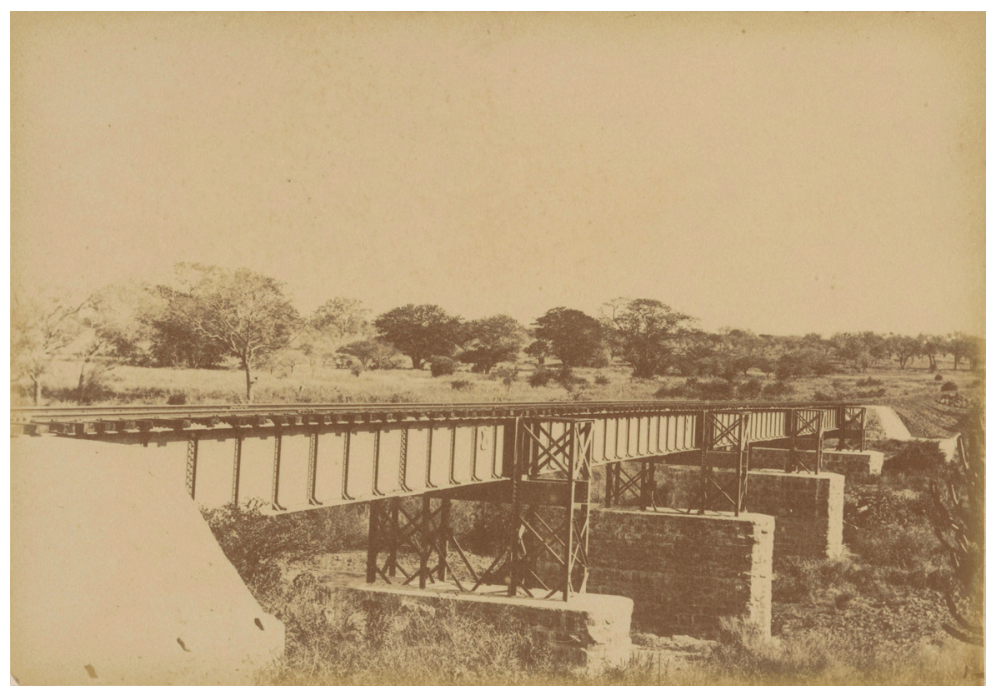

Fonte: CPF, Porto. Ponte sobre a ribeira Chicongene depois de grandes reparações, 1898. Disponível em: < digitarq.cpf.arquivos.pt/details?id=1208378>. Acesso em: 3 jan. 2021. 
Além desse exercício particular, a coleção de fotos da linha de Lourenço Marques apresenta outras facetas, comuns a álbuns semelhantes. Em primeiro lugar, importa realçar o carácter meramente utilitarista das imagens, produzidas no sentido de documentar a construção e servir de ferramenta de auxílio ao trabalho dos engenheiros (OLIVEIRA, 2018, p. 698, p. 702). Todavia, é inegável o papel da fotografia ferroviária na transmissão de determinadas mensagens e na construção de mitos, como o da europeização do território africano, da solidificação da autoridade e soberania portuguesa em Moçambique, da assunção de Portugal como uma nação moderna e imperial ou o da menoridade da população nativa, que carecia do homem branco para se desenvolver (MATOS, 2014a; PEREIRA, 2020, p. 193).

Tal como se verifica noutros álbuns ferroviários, as estações de caminho de ferro encontram-se amplamente registadas no álbum de Romão Pereira. ${ }^{17}$ Embora as gares da linha de Lourenço Marques fossem estruturas simples e nenhuma possuísse detalhes verdadeiramente imponentes (só no início do século XX se construiria em Lourenço Marques uma estação central condigna da importância da ferrovia NAVARRO, 2012, p. 173-179), não deixavam de ser monumentos de progresso que serviam de porta de acesso à linha-férrea e às esperanças de desenvolvimento que nela se depositavam (DEISS, 2013). Em Portugal, diversos textos e declarações atestam o enlevo causado pelas estações. O escritor Manuel Pinheiro Chagas, embora lamentasse a homogeneidade arquitetónica das gares nacionais, descrevia-as como "templos do progresso material" (citado por ABRAGÃO, 1956, p. 65), enquanto o engenheiro Belchior Garcês, numa discussão parlamentar sobre um caminho de ferro em Portugal, garantia que "se trouxermos a uma estação de caminho de ferro o homem menos civilizado (...) e lhe mostrarmos uma locomotiva (...) este homem enthusiasmou-se

17 CPF, Porto. Caminho de Ferro de Lourenço Marques, Gare da estação principal em Lourenço Marques, 1898. Disponível em: <digitarq.cpf.arquivos.pt/details?id=1208370>. Acesso em: 3 jan. 2021. 
necessariamente pelos caminhos de ferro, e o seu primeiro desejo é levar esses caminhos para a sua terra". ${ }^{18}$ No contexto ultramarino, as estações tinham ainda o adicional de contrastar com a natureza e geografia natural envolventes, servindo assim de anunciadores do "progresso" numas paragens representadas como "incivilizadas" e "selvagens".

Um papel semelhante era desempenhado pelas imagens da infraestrutura ferroviária propriamente dita (a linha e as obras de engenharia, como pontes e viadutos). ${ }^{19}$ Tal como acontecia com as estações, nenhuma secção ou obra de engenharia da linha pode ser considerada particularmente impressionante; no entanto, eram igualmente representantes do "progresso", da "civilização" e do engenho europeu. Pontes e viadutos, em específico, demonstravam a conquista de obstáculos geográficos que desde sempre limitavam a mobilidade e a circulação, e a introdução da "ordem" (representada pela retidão das suas linhas matematicamente calculadas) no "caos" da paisagem colonial (representada pelos acidentes naturais circundantes, que Romão Pereira também incluiu nas suas fotos). Em alguns exemplares, nota-se junto a essas obras algumas figuras humanas, incluindo trabalhadores nativos e europeus (possivelmente alguns engenheiros), cuja principal função era servir de escala para o observador percecionar a dimensão das obras fotografadas. Sem embargo, eram também homenagens aos homens que executaram os projetos e demonstrações de que Portugal ministrava a "lição do trabalho" (JERÓNIMO, 2015) aos indígenas (voltarei a esse ponto mais à frente).

Romão Pereira enfatizou ainda a última secção da linha nas últimas 17 fotografias da coleção. ${ }^{20}$ Como referi anteriormente, esse

18 PORTUGAL. Câmara dos Senhores Deputados da Nação Portugueza. Diário da Câmara dos Deputados, 23 mar. 1860. № 20, p. 249.

19 CPF, Porto. Caminho de Ferro de Lourenço Marques, Variante junto à ponte de Chicongene, 1898. Disponível em: < digitarq.cpf.arquivos.pt/details?id=1208377>. CPF, Porto. Dois vãos centraes da nova ponte de Movene, 1898. Disponível em: < digitarq.cpf.arquivos.pt/details ?id=1208385>. Acessos em: 3 jan. 2021.

20 CPF, Porto. Caminho de Ferro de Lourenço Marques, Última secção - troço da linha marginal ao Incomati, 1898. Disponível em: < digitarq.cpf.arquivos.pt/details?id=1208401>. CPF, Porto. 
era o trecho que os empreiteiros ingleses deixaram por fazer e que foi construído sob responsabilidade das autoridades nacionais. Além disso, era a secção que efetivamente fazia a ligação à república transvaliana, de onde se esperavam largas torrentes de tráfego e minério em direção ao porto de Lourenço Marques. A construção de vias-férreas transfronteiriças era um importante ponto da agenda ferroviária portuguesa da época (tanto na metrópole como no ultramar), que pretendia captar o trânsito internacional de pessoas e bens, de modo a reavivar as economias metropolitana e colonial (PEREIRA, 2017). Adicionalmente, tratava-se de tráfego que era desviado dos portos das colónias britânicas do Natal e Cabo (East London, Port Elizabeth, Durban e Cabo) em direção ao ancoradouro português de Lourenço Marques (BOUENE; SANTOS, 2006, p. 240-244). Essas razões decerto motivaram Romão Pereira a dar um foco especial à última secção da linha de Lourenço Marques e a mostrar em fotografias a realização de um importante melhoramento, devido à técnica e investimento nacionais. Ainda que o caminho de ferro empregasse material fixo e circulante britânico, tivesse sido construído com capital britânico e servisse subsidariamente a indústria mineira do Transval, era fotografado e promovido como um feito nacional, demonstrador da capacidade portuguesa de deter e explorar os seus espaços coloniais.

Contrariamente ao que é comum em coleções idênticas (MATOS, 2014a; MACEDO, 2009, p. 291-326), nota-se a quase completa ausência de fotografias de locomotivas e comboios. Não encontro uma explicação satisfatória para essa ausência, que surpreende tendo em conta o impacto visual que normalmente uma locomotiva puxando um comboio acarretava. Provavelmente, quando Romão Pereira retratou a linha, essa não estava ainda em operação, o que obviamente explicaria a ausência de comboios. Por outro lado, talvez não fosse possível disponibilizar uma composição para a objetiva de Romão Pereira ou talvez ele não

Estação definitiva em construção na fronteira, 1898. Disponível em: < digitarq.cpf.arquivos. pt/details?id=1208416>. Acessos em: 3 jan. 2021. 
possuísse a perícia necessária para realizar a fotografia, numa altura em que a baixa velocidade de obturação das máquinas dificultava a captação de movimento e exigia uma técnica mais apurada por parte do fotógrafo.

Até aqui examinei exemplos claros e práticos de aplicações da tecnologia no contexto de Moçambique colonial (portos, telégrafos, armamento, caminhos de ferro), ou elementos representativos de tecnologia no sentido estreito do termo. Romão Pereira fotografou outras estruturas e instituições que são aplicações ou representações do expertise tecnocientífico ocidental, mas num sentido mais lato do conceito.

É o caso dos vários edifícios da administração do Estado (correios, repartições de fazenda e obras públicas, alfândegas, sedes de governo e de câmaras municipais, mercados) captados pela objetiva da sua câmara. ${ }^{21}$ Não sendo o melhor exemplo de uma aplicação tecnocientífica, não deixavam de ser um representante da ciência construtiva e da arquitetura europeias, que, tal como as estações ou as obras de engenharia do caminho de ferro, contrastavam com a maior simplicidade e fragilidade das habitações nativas (que Romão Pereira também fotografou e incluiu nos seus acervos, mas em menor número e com menos relevância). Simultaneamente, eram representantes e amplificadores do poder do Estado português e da sua soberania sobre aqueles territórios. As fotos de Romão Pereira ilustravam essa ampliação da influência do governo metropolitano, mostrando também a eventuais futuros colonos que iriam encontrar em Moçambique as mesmas instituições de administração que usufruíam na metrópole.

Nessa categoria, merece uma análise mais detalhada um tipo de edifício em particular: os hospitais ou outras instituições ligadas à medicina e à saúde (figura 6). Uma das representações mais depreciativas que recaíam sobre as colónias portuguesas era a que as caracterizava como terra de degredo, insalubridade e morte (ALEXANDRE; DIAS,

21 AHU, Lisboa. PEREIRA, Manoel Romão, Repartição de Fazenda, Missão de Mariano de Carvalho, 1890. Disponível em: <actd.iict.pt/view/actd:AHUD6450>. Acesso em: 3 jan. 2021. 
1998, p. 63-64). De facto, um dos maiores obstáculos à penetração dos europeus no sertão africano eram as doenças tropicais, às quais não estavam habituados. De tal modo assim era que o quinino, um composto que debelava algumas doenças tropicais, foi considerado por Headrick (1981, p. 59-60, p. 70) um instrumento de império, que facilitou a penetração europeia em África. Obviamente, infraestruturas hospitalares eram igualmente uma necessidade para o estabelecimento do europeu no contexto colonial. No parlamento português, alguns deputados com interesse pelas e nas colónias registavam precisamente essa necessidade. Era o caso de José Lúcio Travassos Valdez, terceiro conde do Bonfim, um militar português com experiência em África, onde nascera (MÓNICA, 1994, p. 146), que, durante a discussão da alocação de verbas estatais para obras públicas em Moçambique, defendia que não se devia olhar a custos "quando se tem principalmente em vista destruir a insalubridade d'aquelles climas, deseccando os pantanos, construindo os hospitaes necessários para aquellas povoações". ${ }^{22}$ Desse modo, não surpreende que imagens de hospitais também se encontrem facilmente nos trabalhos de Romão Pereira, ${ }^{23}$ como símbolos de "modernidade" e de europeização de África e, novamente, demonstração de que era possível e seguro ao português escolher Moçambique como local de vida. Na segunda foto indicada na nota 23, o detalhe das fardas impecavelmente brancas cimenta essa mensagem de salubridade, higiene e asseio que se pretendia passar.

22 PORTUGAL. Câmara dos Senhores Deputados da Nação Portugueza. Diário da Câmara dos Deputados, 16 abr. 1880. № 72, p. 1449.

23 AHU, Lisboa. PEREIRA, Manoel Romão. Hospital, Missão de Mariano de Carvalho, 1890. Disponível em: <actd.iict.pt/view/actd:AHUD6490>. AHU, Lisboa. PEREIRA, Manoel Romão, Novo pavilhão annexo ao hospital militar e civil, África Oriental, 1889-1891. Disponível em: <actd.iict.pt/view/actd:AHUD6346>. Acessos em: 3 jan. 2021. 
Figura 6: Vista panorâmica do hospital civil e militar de Lourenço Marques

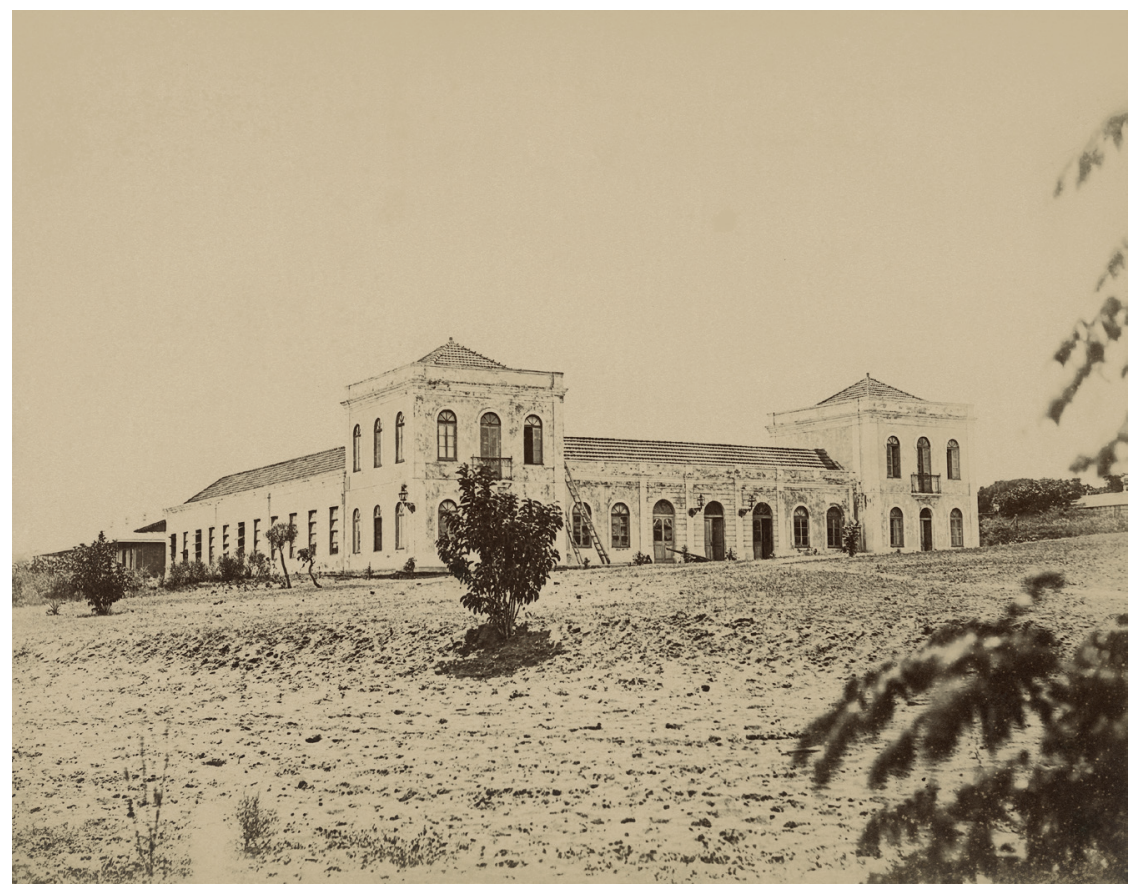

Fonte: AHU, Lisboa. PEREIRA, Manoel Romão. O Hospital Civil e Melitar [sic], África Oriental, 1889-1891. Disponível em: <actd.iict.pt/view/actd:AHUD6376>. Acesso em: 3 jan. 2021.

Função semelhante (buscando objetivos idênticos) desempenhavam as várias fotografias que retravam aspetos urbanos das cidades moçambicanas, como avenidas, ruas cortando selvas, jardins ou casas de habitação. ${ }^{24}$ Tal como acontecia com as fotos de edifícios oficiais, essas imagens de construções civis representavam a engenharia e arquitetura europeia e mostravam uma efetiva ocupação, "domesticação" e "europeização" do território, enquanto o poderiam publicitar junto

24 AHU, Lisboa. PEREIRA, Manoel Romão, Quelimane - Avenida Castello lado da Bahia, vista do caes de desembarque, África Oriental, 1889-1891. Disponível em: <actd.iict.pt/view/actd: AHUD6350>. AHU, Lisboa. PEREIRA, Manoel Romão. Lourenço Marques - Avenida D. Manuel, 1889-1891. Disponível em: <actd.iict.pt/view/actd:AHUD6343>. Acessos em: 3 jan. 2021. 
dos portugueses que viviam na metrópole e que com esse argumento visual podiam ser persuadidos a migrar para as colónias. Aqui importa referir que a migração de portugueses para as colónias era ainda bastante reduzida (os migrantes preferiam claramente o Brasil) e que uma das preocupações dos sucessivos governos portugueses era redirecionar esses fluxos para os domínios ultramarinos (LAINS, 1998, p. 467). Nesse sentido, a fotografia podia ser um útil auxiliar.

Ainda nas cidades, imagens de edifícios religiosos da fé católica (figura 7$)^{25}$ ilustravam a combinação da técnica europeia e do impacto visual da grande obra pública (visível no contraste com a pequenez de elementos circundantes) com o impacto da fé e da religião católica, o qual era também incluído com conceito de "progresso" e na "missão "civilizadora" de Portugal em Moçambique. Como dizia no parlamento nacional o já citado conde de Bonfim, numa interpelação que dirigiu ao governo sobre o estado da colónia de Moçambique:

o clero portuguez, a quem está incumbida uma tão alta missão, a de desenvolver a propaganda religiosa no ultramar (...) concorrerá e empregará todos os meios ao seu alcance e influencia, para fazer desenvolver as missões religiosas na Africa, concorrendo assim para (...) [a] obra do progresso. ${ }^{26}$

Em alguns aspetos, tecnologia e religião tinham pontos em comum, no sentido em que ambas evocam sensações de omnipotência, transcendência e salvação, pelo que ambas se entrecruzaram em simbiose (NOBLE, 1997, p. 15-16, p. 22-28). A fotografia contribuía para exponenciar esta aliança.

25 AHU, Lisboa. PEREIRA, Manoel Romão. Egreja [sic] de S. Paulo e Residência do Governador Geral, Missão de Mariano de Carvalho, 1890. Disponível em: <actd.iict.pt/view/actd: AHUD6448>. Acesso em: 3 jan. 2021.

26 PORTUGAL. Câmara dos Senhores Deputados da Nação Portugueza. Diário da Câmara dos Deputados, 27 jan. 1880. № 17, p. 256. 
Figura 7: Vista da igreja paroquial de Lourenço Marques

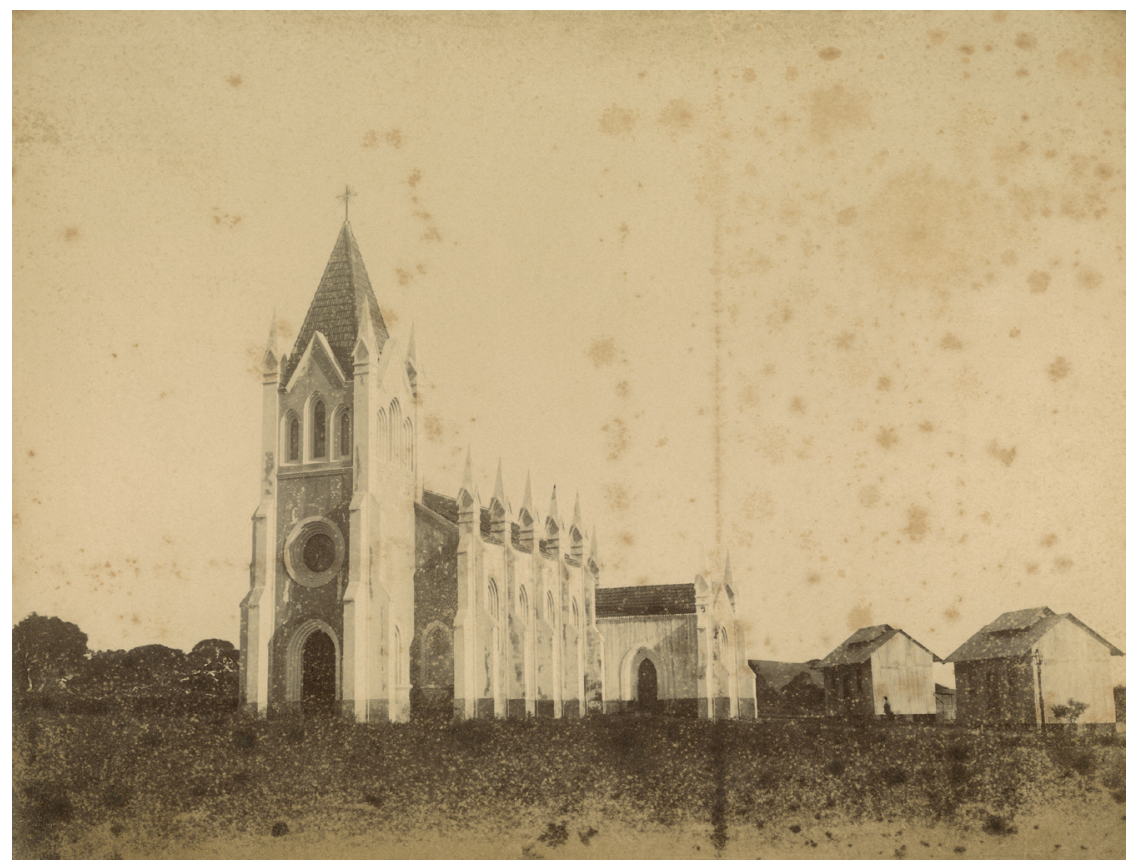

Fonte: AHU, Lisboa. PEREIRA, Manoel Romão. Igreja Paroquial, África Oriental, 1889-1891. Disponível em: < actd.iict.pt/view/actd:AHUD8859 >. Acesso em: 3 jan. 2021.

Para terminar, analiso imagens que ilustram parte da interação entre a tecnologia colonizadora e o nativo colonizado, ressalvando, porém, que esse tipo de retratos não é frequente na obra de Romão Pereira. Algumas dessas fotografias retratam estruturas de exploração agrícola (plantações) e industrial (pequenos fornos) dos recursos de Moçambique, incluindo na composição uma ou mais figuras negras. ${ }^{27}$ Encontro nessas imagens duas mensagens específicas: em primeiro lugar, aquela que defendia que Portugal tinha capacidade para explorar os recursos

27 AHU, Lisboa. PEREIRA, Manoel Romão. Prazo Mahindo - Forno de cozer telha e tijolo, Missão de Mariano de Carvalho, 1890. Disponível em: <actd.iict.pt/view/actd:AHUD6508>. AHU, Lisboa. PEREIRA, Manoel Romão. Fazenda agrícula [sic] em Miranbaque - Pessoal da colheita da cana seca, África Oriental, 1889-1891. Disponível em: <actd.iict.pt/view/actd: AHUD6299>. Acesso em: 3 jan. 2021. 
coloniais sob sua responsabilidade; em segundo, a demonstração de que Portugal ministrava a "lição do trabalho" ao nativo e concorria assim para a sua "educação" e "civilização". Como demonstrou recentemente Jerónimo (2015), a imposição de obrigações laborais aos nativos colonizados fazia parte da "missão civilizadora" de Portugal nas suas colónias. A esse respeito, o deputado João Arroio, um destacado jurisconsulto português (MÓNICA, 2006, p. 222-224), discorrendo sobre os resultados da Conferência de Berlim, defendia a necessidade imperiosa de

regular um bom regimen de trabalho da raça negra, curando de a civilisar, coarctando-lhe sensatamente as suas tendencias preguiçosas, que se manifestam assegurado que seja o sustento diario, quando são dominadas pelo instincto da conservação, e cujas consequencias são o rebaixamento do nivel moral da raça, o habito da embriaguez e a producção dos actos criminosos. ${ }^{28}$

Sem estar desligado da obrigação do trabalho, a educação do nativo fazia também parte da "missão civilizadora" e de "aportuguesamento" e da agenda tecnocientífica portuguesa (JERÓNIMO, 2015, p. 61). Num outro trecho do seu discurso, o mesmo João Arroio afirmava que a

abolição da escravatura, sem o ensino e a vigilancia especial sobre o trabalho da raça libertada, pouco mais é do que uma mera illusão; o preto, apparentemente livre, continua escravo da sua mentalidade infantil e da sua preguiça congenita. O negro só será verdadeiramente livre quando for illustrado, trabalhador por habito, sobrio por educação e activo por interesse de parceria commercial ou industrial. ${ }^{29}$

28 PORTUGAL. Câmara dos Senhores Deputados da Nação Portugueza. Diário da Câmara dos Deputados, 19 jun. $1885 . \mathrm{N}^{\circ} 18$, p. 2453.

29 PORTUGAL. Câmara dos Senhores Deputados da Nação Portugueza. Diário da Câmara dos Deputados, 19 jun. 1885, № 18, p. 2450. 
Esse excerto do discurso daquele deputado evidencia também que a formação do nativo não era um fim em si, mas tinha um objetivo muito específico, qual era o de o preparar para o trabalho que alegadamente o haveria de libertar da sua preconcebida "preguiça congénita" ${ }^{30} \mathrm{~A}$ fotografia e o seu imediatismo tinham o condão de realçar apenas a primeira parte (a educação) e o momento do ensino, ofuscando o seu corolário (o trabalho forçado). Desse modo, adicionava-se mais um argumento à "missão civilizadora" e à paisagem tecnocientífica que se criava da África colonial portuguesa. Uma das fotos de Romão Pereira aborda precisamente essa prática educativa (figura 8), mostrando um conjunto de crianças moçambicanas com o seu professor, o padre Simões, dando assim representação visual às aspirações da agenda colonial nacional. No entanto, como já referi, importa realçar que essas fotos são claramente minoritárias na coleção de Romão Pereira, que preferia outro tipo de motivos, pelo que essas conclusões são naturalmente mais frágeis.

Figura 8: Alunos nativos, com o professor português da escola municipal para crianças do sexo masculino de Lourenço Marques

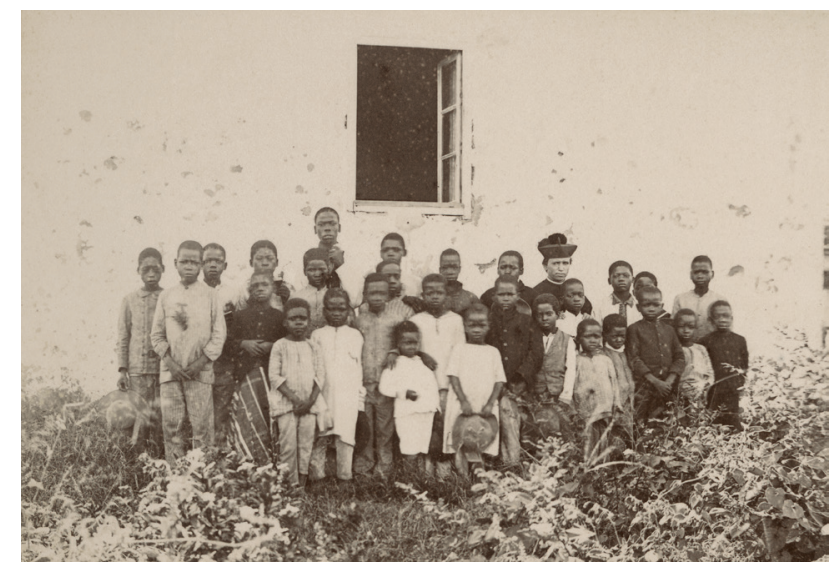

Fonte: AHU, Lisboa. PEREIRA, Manoel Romão. Escola do Sexo Masculino municipal, África Oriental, 1889-1891. Disponível em: < actd.iict.pt/view/actd:AHUD6357 >. Acesso em: 3 jan. 2021.

30 Ver também JERÓNIMO, 2015, p. 39-41, p. 91-96. 
Embora não se enquadre exatamente nos objetivos deste artigo (que se debruça sobre atividades tecnocientíficas nas fotografias de Romão Pereira), gostaria de abordar brevemente um outro detalhe: a forma como a fotografia foi praticada não para retratar elementos tecnocientíficos, mas como ela própria se constitui em uma prática tecnocientífica ao serviço da etnografia e da antropologia, que procurava classificar as populações nativas. Tal como se verifica em outras coletâneas, diversas fotos de Romão Pereira mostram tipos humanos, numa putativa tentativa de inventariar as etnias locais e completar uma antropologia de Moçambique (MATOS, 2014b, p. 45-48; ROCHA; MATOS, 2019, p. 167-172). Noutras, como já referi, os negros (seus trajes e habitações) são perfilados com estruturas tecnocientíficas europeias, enfatizando-se a diferença entre os elementos europeus (conotados com o "progresso") e os elementos nativos (conotados com "primitivismo", isto é, ausência das estruturas organizativas e materiais que existiam na Europa). Os nativos não eram identificados e eram tidos como representantes de toda a etnia e não como indivíduos, sendo por isso também desumanizados, além de insinuados como seres inferiores, carentes da orientação ocidental (ROCHA; MATOS, 2019, p. 173-175). Nesse sentido, essas fotografias continham uma violência inerente, uma vez que os retratados eram instrumentalizados para produzir uma determinada imagem deles próprios (cf. AZOULAY, 2008, p. 95, p. 100), concorrendo assim para a relação desigual de poder entre colonizador e colonizado.

Munida da sua alegada objetividade, essas (e outras) fotografias contribuíram para validar cientificamente tais asserções, que, repetidas em diversas chapas e na imprensa, construíam ideários estereotipados e racistas que em certos pontos perduraram até aos nossos dias. Essa é uma linha de investigação importante e que não pode mesmo ser dissociada das histórias da ciência e da tecnologia no contexto colonial, que atuavam como justificativos da alegada inferioridade dos africanos face aos ocidentais. 


\section{Conclusão}

Ao se focar nos aspetos tecnocientíficos da presença portuguesa em Moçambique, Romão Pereira forneceu aos observadores dos seus trabalhos uma paisagem tecnocientífica da colónia, baseada numa visão subjetiva, parcial e enviesada da mesma. Aqueles que na metrópole olhassem para as suas fotos, quer folheando os álbuns, quer na imprensa, quer mirando-as na Exposição Colonial do Porto, viam uma colónia moderna, repleta de estruturas e ferramentas de "progresso", desde caminhos de ferro a hospitais, passando por edifícios civis, militares e religiosos. Especulando, posso dizer que muitos poriam a opção de emigrar para Moçambique e não para o Brasil.

Num segundo plano, essa paisagem tecnocientífica criada por Romão Pereira contribuía para construir a ideia de um Portugal moderno, com uma agenda colonial, com capacidade imperial e capaz de encetar a sua "missão civilizadora" à semelhança de outras nações imperiais. Nesse sentido, o nativo colonizado era colocado numa relação de poder desigual, instrumentalizado num discurso visual tecnocientífico como um ser primitivo, carente da orientação "civilizadora" do colono português.

As fotos de Romão Pereira retratavam uma ínfima parte da realidade colonial. Os caminhos de ferro em operação na altura (além do de Lourenço Marques, o da Beira) não só tinham zonas de influência muito limitadas e condições de circulação muito precárias, como estavam vocacionados para o tráfego transfronteiriço, de modo que a maioria esmagadora do território deles não retirava qualquer benefício. Fora das cidades (Lourenço Marques, Beira ou Quelimane), a ausência do telégrafo tornava as comunicações lentas; sem hospitais, os colonos sujeitavam-se à doença do sono ou à malária; a influência do Estado (em termos de segurança e administração do território) era entre ténue e inexistente. Os portos, se aparentemente eram umbrais para o império, na prática eram de difícil acesso. Em suma, o contexto colonial era composto na sua generalidade por terras onde o propalado "progresso" ocidental que se via nas fotos de Romão Pereira não tinha chegado. 
Contudo, a objetividade (e, em certa medida, ainda a novidade) que era atribuída à fotografia promovia a sobrevalorização dos vislumbres do império fornecidos pelo fotógrafo português, tornava-os janelas privilegiadas (e únicas) para a realidade africana, que, ainda que abertas sobre partes muito restritas das colónias, eram tomadas pelos que as observavam como se o todo colonial representassem.

Para concluir, este artigo, ainda que constituindo apenas um caso de estudo sobre um acervo específico (as fotografias de Romão Pereira), demonstra a utilidade e a relevância da fotografia e do campo da cultura visual para a área da história da ciência e da tecnologia e também para a análise dos processos coloniais e da criação e difusão das representações originadas durante o colonialismo.

\section{Agradecimentos}

Gostaria de agradecer o apoio académico e institucional fornecido pelo CIUHCT - Centro Interuniversitário de História das Ciências e da Tecnologia (UID/HIS/00286) e pelo Department of History of the University of York e o apoio financeiro fornecido pela Fundação para a Ciência e a Tecnologia através da moldura legal criada pelo decreto-lei 57/2016 e lei 57/2017.

\section{REFERÊNCIAS BIBLIOGRÁFICAS}

ABRAGÃO, Frederico de Quadros. Cem anos de caminho de ferro na literatura portuguesa. Lisboa: CP, 1956.

ADAS, Michael. Machines as the Measure of Men. Science, Technology, and Ideologies of Western Dominance. Ithaca: Cornell University Press, 1989. ADAS, Michael. Dominance by Design: Technological Imperatives and America’s Civilizing Mission. Cambridge: Harvard University Press, 2006.

ALEXANDRE, Valentim; DIAS, Jill (coord.). O Império Africano: 18251890. In: SERRÃO, Joel; MARQUES, António Henrique R. de Oliveira (dir.). Nova história da expansão portuguesa. Lisboa: Estampa, 1998. v. 9. 
ALLINA, Eric. Fallacious Mirrors: Colonial Anxiety and Images of African Labor in Mozambique, ca. 1929. History in Africa, v. 24, p. 9-52, 1997. AZOULAY, Ariella. The Civil Contract of Photography. New York: Zone Books, 2008.

BARTHES, Roland. A Câmara clara. Nota sobre fotografia. Rio de Janeiro: Nova Fronteira, 1980.

BEEGAN, Gerry. The Mass Image. A Social History of Photomechanical reproduction in Victorian London. Basingstoke: Palgrave Macmillan, 2008. BOUENE, Felizardo; SANTOS, Maciel. O Modus vivendi entre Moçambique e o Transvaal (1901-1909). Um caso de "imperialismo ferroviário". Africana Studia, n. 9, p. 239-269, 2006.

COSTANTINI, Dino. Mission civilisatrice. Le rôle de l'histoire coloniale dans la construction de l'identité politique française. Paris: La Découverte, 2008.

DEISS, Richard. The Cathedral of the Winged Wheel and the Sugar Beet Station. Trivia and Anecdotes on 222 Railway Stations in Europe. Bona: Herstellung und Verlag, 2013.

DIAS, Jill R. Photographic Sources for the History of Portuguese-speaking Africa, 1870-1914. History in Africa, v. 18, p. 67-82, 1991.

DIREITO, Bárbara. Caçados e caçadores nas fotografias do arquivo da Companhia de Moçambique. In: VICENTE, Filipa Lowndes (Ed.). O Império da visão. Fotografia no contexto colonial português (1860-1960). Lisboa: Edições 70, 2014. p. 141-155.

DUBOIS, Philippe. O Acto fotográfico. Lisboa: Vega, 1992.

FERNANDES, Paulo Jorge. A fotografia e a edificação do Estado Colonial: a missão de Mariano de Carvalho à província de Moçambique em 1890. In: VICENTE, Filipa Lowndes (Ed.). O Império da visão. Fotografia no contexto colonial português (1860-1960). Lisboa: Edições 70, 2014. p. 195-210. FRANKLIN, Margery B.; BECKLEN, Robert C.; DOYLE, Charlotte L. The Influence of Titles on how Paintings are seen. Leonardo: Journal of the International Society for the Arts, Sciences and Technology, v. 26, n. 2, p. 103-108, 1993.

FREUND, Gisèle. Fotografia e sociedade. Lisboa: Vega, 1995. 
GOMES, Inês Vieira. A Souvenir of Lourenço Marques: álbuns fotográficos de C. S. Fowler, J. \& M. Lazarus e José dos Santos Rufino (1887-1929). Outros Tempos, v. 13, n. 22, p. 163-176, 2016.

GUIMARÃES, Ângela. Uma Corrente do colonialismo português: a sociedade de geografia de Lisboa. Lisboa: Livros Horizonte, 1984.

HALL, Catherine. Civilising Subjects: Metropole and Colony in the English Imagination 1830-1867. Chicago: University of Chicago Press, 2002.

HEADRICK, Daniel R. The Tools of Empire. Technology and European Imperialism in the Nineteenth Century. Oxford: Oxford University Press, 1981.

HEADRICK, Daniel R. Power over Peoples. Technology, Environments, and Western Imperialism, 1400 to the Present. Princeton: Princeton University Press, 2010.

JACKSON, John Brinckerhoff. Discovering the Vernacular Landscape. New Haven: Yale University Press, 1984.

JERÓNIMO, Miguel Bandeira. The 'Civilising Mission' of Portuguese Colonialism, 1870-1930. Basingstoke: Palgrave Macmillan, 2015.

JESSETT, Montague George. The Key to South Africa: Delagoa Bay. Londres: T. Fisher Unwin, 1900.

KASSON, John F. Civilizing the Machine: Technology and Republican Values in America, 1776-1900. Nova York: Grossman Publishers, 1976. KELSEY, Robin. Is Landscape Photography? In: DOHERTY, Gareth; WALDHEIM, Charles (Ed.). Is landscape...? Essays on the Identity of Landscape. Londres: Routledge, 2016. p. 71-92.

LAINS, Pedro. Causas do colonialismo português em África, 1822-1975. Análise Social, v. 33, n. 146-147, p. 463-496, 1998.

LANDAU, Paul S.; KASPIN, Deborah D. (Ed.). Images and Empires. Visuality in Colonial and Postcolonial Africa. Berkeley: University of California Press, 2002.

MACEDO, Marta Coelho de. Projectar e construir a nação. Engenheiros e território em Portugal (1837-1893). Dissertação (Doutoramento em Arquitetura) - Universidade de Coimbra, Coimbra, 2009. 
MANGOELE, Márcio de Nino Lourenço. As Campanhas militares portuguesas no centro e norte de Moçambique 1886-1916. Relatório científico (Trabalho de Investigação Aplicada) - Academia Militar, Lisboa, 2015. MARQUES, A. H. de Oliveira (coord.). O Império Africano: 1890-1930. In: SERRÃO, Joel; MARQUES, A. H. de Oliveira (dir.). Nova história da expansão portuguesa. Lisboa: Estampa, 2001. v. 10.

MARTINS, Leonor Pires. Um Império de papel. Imagens do colonialismo português na imprensa periódica ilustrada (1875-1940). Lisboa: Edições 70, 2014.

MATOS, Ana Cardoso de. Os Testemunhos fotográficos da obra pública em Portugal. In: AGUILAR, Inmaculada; DOMÉNECH, Sergi (Ed.). Fotografía y obra pública. Valencia: Conselleria d'Infraestructures, Territori i Medi Ambient, 2014a. p. 11-29.

MATOS, Patrícia Ferraz de. As Côres do Império: representações raciais no Império colonial português. Lisboa: Imprensa de Ciências Sociais, 2006. MATOS, Patrícia Ferraz de. A fotografia na obra de Mendes Correia (1888-1960): modos de representar, diferenciar e classificar da "antropologia colonial”. In: VICENTE, Filipa Lowndes (ed.). O Império da visão. Fotografia no contexto colonial português (1860-1960). Lisboa: Edições 70, 2014b. p. 45-66.

MIRZOEFF, Nicholas. The Subject of Visual Culture. In: MIRZOEFF, Nicholas (Ed.). The Visual Culture Reader. Londres: Routledge, 2002. p. 3-23.

MITCHELL, William J. T. Introduction. In: Landscape and Power. Chicago: The University of Chicago Press, 1994. p. 1-4.

MÓNICA, Maria Filomena. A Lenta morte da Câmara dos Pares (18781896). Análise Social, Lisboa, v. 29, n. 125-126, p. 121-152, 1994.

MÓNICA, Maria Filomena (Ed.). Dicionário biográfico parlamentar (1834-1910). Lisboa: Imprensa de Ciências Sociais, 2006.

NAVARRO, Bruno J. A Estação Central de Maputo no contexto das políticas de preservação do património edificado de Moçambique: estudo de caso. Historiae, v. 3, n. 1, p. 171-200, 2012.

NAVARRO, Bruno J. Um Império projectado pelo "silvo da locomotiva". O papel da engenharia portuguesa na apropriação do espaço colonial africano. Angola e Moçambique (1869-1930). Lisboa: Colibri, 2018. 
NOBLE, David. The Religion of Technology. The Divinity of man and the spirit of invention. Nova York: Alfred A. Knopf, 1997.

NYE, David E. Technologies of Landscape: from Reaping to Recycling. Amherst: University of Massachusetts Press, 1999.

OLIVEIRA, Eduardo Romero. Photographic views of Railroads: recording Public Works in Nineteenth Century Brazil. História, Ciências, Saúde Manguinhos, v. 25, n. 3, p. 695-723, 2018.

PAVAN, Margot. Fotomontagem e pintura pré-rafaelista. In: FABRIS, Annateresa (Ed.). Fotografia: usos e funções no século XIX. São Paulo: EDUSP, 1991. p. 233-260.

PÉLISSIER, René. Naissance du Mozambique: résistance et révoltes anticoloniales. Lisboa: Estampa, 1984.

PEREIRA, Hugo Silveira. Fronteiras e caminhos-de-ferro: da quimera Saint-Simoniana ao desencanto tecnodiplomático (c. 1850-c. 1900). Revista de História das Ideias, v. 35, p. 227-259, 2017.

PEREIRA, Hugo Silveira. Portais de globalização: portos e caminhos de ferro no contexto colonial português (c. 1870 - c. 1910). Revista Portuguesa de História, v. 49, p. 227-239, 2018.

PEREIRA, Hugo Silveira. O caminho de ferro da Beira em Moçambique (1890-1914): entre antagonismo tecnodiplomático e simbiose económica. Análise Social, v. 54, n. 233, p. 694-724, 2019.

PEREIRA, Hugo Silveira. Visões do Império: a coleção fotográfica da brigada de estudo e construção do caminho de ferro de Moçâmedes (c. 1907 - c. 1914). Revista de História da Sociedade e da Cultura, v. 20, p. 171-196, 2020.

PEREIRA, Luísa Vilarinho. Moçambique. Manoel Pereira (1815-1894). Fotógrafo comissionado pelo Governo Português. Lisboa: (s.n.), 2013. PHU, Thy. Vietnamese Photography and the Look of Revolution. In: SMITH, Shawn Michelle; SLIWINSKI, Sharon (Ed.). Photography and the Optical Unconscious. Durham: Duke University Press, 2017. p. 286-320.

PORTUGAL, Ministério das Colónias. Estatística dos caminhos de ferro das colónias portuguesas de 1888 a 1915. Documentos principais e gráficos. Lisboa: Imprensa Nacional, 1917. 
ROCHA, Liliana Oliveira da; MATOS, Patrícia Ferraz. Fotografias de Angola do Século XIX: o "Álbum Fotográfico-Literário" de Cunha Moraes. Tempos e Espaços em Educação, v. 12, n. 31, p. 165-186, 2019.

RYAN, James R. Picturing Empire. Photography and the visualization of the British Empire. Chicago: The University of Chicago Press, 1997.

RYAN, James R. Introdução. Fotografia colonial. In: VICENTE, Filipa Lowndes (Ed.). O Império da visão. Fotografia no contexto colonial português (1860-1960). Lisboa: Edições 70, 2014. p. 31-42.

SANTANA, Noeme. Olhares britânicos: visualizar Lourenço Marques na ótica de J and M Lazarus, 1899-1908. In: VICENTE, Filipa Lowndes (Ed.). O Império da visão. Fotografia no contexto colonial português (1860-1960). Lisboa: Edições 70, 2014. p. 211-222.

SILVA, Cristina Nogueira. O Registo da diferença: fotografia e classificação jurídica das populações coloniais. In: VICENTE, Filipa Lowndes (Ed.). O Império da visão. Fotografia no contexto colonial português (1860-1960). Lisboa: Edições 70, 2014. p. 67-84.

SENA, António. História da imagem fotográfica em Portugal - 1839-1997. Porto: Porto Editora, 1998.

SONTAG, Susan. Ensaios sobre fotografia. Lisboa: Dom Quixote, 1986.

TEIXEIRA, Nuno Severiano. Política externa e política interna no Portugal de 1890: o ultimatum inglês. Análise Social, v. 23, n. 98, p. 687-719, 1987. TELO, António José. Lourenço Marques na política externa portuguesa. Lisboa: Cosmos, 1991.

VICENTE, Filipa Lowndes (Ed.). O Império da visão. Fotografia no contexto colonial português (1860-1960). Lisboa: Edições 70, 2014a.

VICENTE, Filipa Lowndes. O Império da visão: histórias de um livro. In: VICENTE, Filipa Lowndes (Ed.). O Império da visão. Fotografia no contexto colonial português (1860-1960). Lisboa: Edições 70, 2014b. p. 11-30. 